\title{
Envisioning Doom or Hope for the Midwestern Small Town: A Review Essay
}

\author{
JAN OLIVE NASH
}

Community of Strangers: Change, Turnover, Turbulence, and the Transformation of a Midwestern Country Town, by Joseph A. Amato and John Radzilowski. Marshall, MN: Crossings Press, 1999. xiii, 109 pp. Notes, tables, charts, bibliography. $\$ 11.95$ paper.

Lancaster, Ohio, 1800-2000: Frontier Town to Edge City, by David R. Contosta. Urban Life and Urban Landscape Series. Columbus: Ohio State University Press, 1999. xx, 333 pp. Illustrations, maps, bibliographical essay, notes, index. $\$ 37.50$ cloth.

STUDYING SMALL TOWNS is a lot like examining an elephant. The closer you get, the less coherent they become as a whole. Like the constructs of urbanization and modernization, the definition of small town changes with the writer, and urban historians and metropolitan writers are hard-pressed to define their subjects without small towns and rural areas to use as contrast. The terminology is imprecise and deceptively slippery. In contrast to a rural area, a small town is urban; in contrast to Chicago, however, a small town is rural.

In the nineteenth and early twentieth centuries, writing the history of small towns was largely the domain of the amateur historian who crafted countywide histories for local audiences. Those amateur historians often viewed communities as isolated from each other, islands of civilization created by unique leaders and surrounded by a sea of potential economic resources. Formu-

THE ANNALS OF IOWA 59 (Fall 2000). (T) State Historical Society of Iowa, 2000. 
laic community histories were written by locally prominent men, paid for by subscriptions of locally successful businessmen and farmers, and published by companies in urban printing centers such as Chicago and Cincinnati.

Frederick Jackson Turner challenged the habit of viewing small towns in isolation from each other in 1893, when his frontier thesis linked communities together. For Turner, the frontier moved successively westward across the nation during the nineteenth century. In a repetitive pattern, settlers created small towns in a predictable cycle following removal of the American Indians, abandonment of the land by hunters and traders, and conversion of the countryside to farmland. Turner's small towns played a special role on the prairie, nurturing democratic values and converting Europeans into Americans.

By the 1920s, World War I and technological advances had Americans thinking more about how small towns were adjusting to a modern world than about how they were created on the American frontier. Progressive historians, Mary and Charles Beard among them, were optimistic about the promise of the machine age and foresaw unlimited progress in its wake. ${ }^{2}$ Automobiles, telephones, and rural electrification, after all, eased the burdens and isolation of country folk and shrank the distance between country towns. Robert and Helen Merrell Lynd's Middletown series (focused on Muncie, Indiana, and published in 1929 and 1937) was a landmark study of the effect of modernization on small towns. Combining cultural anthropological and sociological methods, the Lynds sought to understand Muncie's rate of adjustment to rapid change introduced from outside the community. "Cultural lag," the Lynds' term for the delay between the acceptance of new material conditions and the slower cultural endorsement of novel behaviors and

1. See Frederick Jackson Turner, The Frontier in American History (1920; reprint, Tucson, 1994).

2. Charles A. Beard and Mary R. Beard, The Rise of American Civilization (New York, 1930). Thorstein Veblen, in contrast, cast nineteenth-century midwestern country towns as repetitious and wasteful, occupied by speculators who inflated land values and greedy merchants who charged excessive prices for goods and services needed by farmers. See "The Country Town" (1923), in The Collected Works of Thorstein Veblen (London, 1994), 9:144-45. 
ideas, is still popularly understood as an explanation of the tensions in modern small-town life." The advent of a "wired" countryside in a postmodern age, where cable service and highspeed Internet connections are possible, is yet to be well studied, in Muncie or anywhere else.

World War II increased the uneasy relationship Americans had with technology and the modern world order. In the face of postwar conflicts and developing Cold War tensions, historians revisited the subject of small-town America, looking for signs of stability and core democratic values. Merle Curti found them in nineteenth-century Trempealeau County, Wisconsin, where individual opportunity and the need to work together to solve common problems Americanized new arrivals, most of whom were Norwegians. Small towns, in Curti's view, were the agents of the melting pot; they were where immigrants of diverse backgrounds learned and adopted democratic values and where a shared American culture settled gently but firmly over their lives. About the same time, Lewis Atherton captured the details of nineteenth-century daily life in midwestern communities, right down to the mingled aroma of hay and horse urine that drifted from the open doors of the Main Street livery stable. Atherton also viewed small towns as incubators of American values. The survival of those small towns in a modern world, he posited, would require maintenance of a sense of "togetherness," not just a small size or rural setting. ${ }^{4}$

Scholarship on the small town since the 1960s reflects the "new social history," a reorientation of historical analysis on the magnitude of an "earthquake." ${ }^{5}$ The new social history broadened the analysis to include more than the small towns' white Protestant elite or the pioneering families of Yankee or northern European extraction. Now women, persons of color, laborers,

3. Robert S. Lynd and Helen Merrell Lynd, Middletown, A Study in Contemporary American Culture (New York, 1929); idem, Middletown in Transition: A Study in Cultural Conflicts (New York, 1937).

4. Merle Curti, The Making of an American Community: A Case Study of Democracy in a Frontier County (Stanford, CA, 1959); Lewis Atherton, Main Street on the Middle Border (Bloomington, IN, 1954), 285.

5. Alice Kessler-Harris, "Social History," in Eric Foner, ed., The New American History (Philadelphia, 1990), 163. 
and new immigrants were given a voice. And, in a shift that resonated of Middletown and Muncie's struggle with modernization, considerable evidence of conflict surfaced in the new studies of nineteenth-century communities. Robert Dykstra, for one, found such evidence among Kansas merchants, the Texas cattlemen who drove their longhorns north to the Kansas railheads, and the increasing numbers of newly arrived farmers whose interests dictated fencing out the cattle from their traditional resting grasslands. ${ }^{6}$

The new social history also included a rethinking of the theoretical boundaries of "community" and an uncoupling of the experience of community from the physical place. This subjective quality of how small-town residents experienced their lives in relation to other residents had been identified twenty years before by Lewis Atherton, who cast it as an essential criterion for small-town survival in the future. Thomas Bender extended Atherton's conclusion, arguing in the late 1970s that historians had adopted the sociological model of community evolution too completely. The model was actually one of community breakdown and, as such, inevitably led to the conclusion that small towns were moribund. Indeed, community studies that proliferated in the 1960s and '70s-most of which looked at New England towns-focused on the breakup of communities under forces beyond their control. Placed in chronological order, the case studies "portray the collapse of community during the lives of several successive generations of Americans" and were impossible to synthesize for overarching patterns or themes. "Which study accurately captures the moment of collapse?" Bender asked. "How many times can community collapse in America?" Instead, he suggested exploring the question of how people manage simultaneously to live in a modern world and to maintain traditional bonds of community with family and neighbors.

By the 1980s, then, the stage was set, and the story could have at least two plot lines. Small towns (and by implication the

6. Robert Dykstra, The Cattle Towns (New York, 1968).

7. Thomas Bender, Community and Social Change in America (1978; reprint, Baltimore, 1982), 49. 
countryside surrounding them) were either inextricably caught in a downward spiral of vacant Main Streets, decaying neighborhoods, and abandoned public spaces, or they might reinvent themselves, adapt to new conditions, and somehow maintain a sense of themselves as cohesive, hopeful communities with a future.

Historians in the 1980s and early '90s shifted the focus from old New England to midwestern towns founded during the nineteenth century. John Mack Faragher's Sugar Creek: Life on the Illinois Prairie (1986) explained the creation of community bonds and traditions in a cashless frontier neighborhood. In River Towns in the Great West (1990), Timothy Mahoney explored town formation in advance of rural settlement and the role of geography in site selection, a line of thought rooted in Richard C. Wade's The Urban Frontier (1959). The merger of environmental conditions and town development also structured William Cronon's study of Chicago's emergence as the primary midwestern entrepôt and its relationship to distant small towns (Nature's Metropolis, 1991).

Not all writers focused on existing or historic towns. The creation since the 1970s of new towns, called "edge cities," was an intriguing notion advanced by Joel Garreau in Edge City: Life on the New Frontier (1988). Garreau argued that edge cities form at the outskirts of large cities or along busy transportation routes and intersections, in part because commuters grow weary of traveling long distances to work or to shop. Edge cities have all the hallmarks of self-contained towns, where people live, work, shop, and play within the same area. In Iowa, the I35 corridor north of Des Moines and the intersection of Interstates 80 and 380 in eastern Iowa may be emerging edge cities.

Much of the work on midwestern communities in the past few years has focused on the status of small towns under stress from the latest agricultural crisis of the 1980s. In Broken Heartland: The Rise of America's Rural Ghetto (1996), Osha Gray Davidson painted a bleak picture of small towns as places of poverty, abuse, and hopelessness. Stagnation and the deterioration of community traditions had hit Camden, Ohio, hometown of historian Richard O. Davies, as early as the mid-1950s, however. His nuanced study, Main Street Blues: The Decline of Small-Town 
America (1998), acknowledged the complex of internal factors and distant influences that combined to push Camden, like so many other midwestern small towns, into slow decline. Davies articulated, and then left for future researchers to fully develop, the adverse effect of federal policies and transportation systems on small-town America.

Others remain more optimistic about small towns and their icon, Main Street. Richard Francaviglia, for example, included in Main Street Revisited (1996) communities ranging from 750 to 30,000 people and concentrated on the role of the communities' built environments. He called those communities both place and symbol and found the promise of life in them even after the arrival of Wal-Mart. Researchers at the Heartland Center for Leadership Development employed a methodological approach similar to one the Lynds used in their study of "Middletown," but avoided the community breakdown model by looking specifically at "thriving" small towns, from 300 to 6,000 in population, located in Nebraska, Iowa, Michigan, Minnesota, Ohio, and the Dakotas. Milan Wall, codirector of the center, discussed six traits that enabled even the most remotely located communities to thrive: community attitude (such as community pride); economic enterprise; political and social inclusiveness (including a willingness to transfer power to younger leaders and recognition of women leaders); forward thinking; use of traditional institutions; and internal leadership. Leadership in all its forms was "a highly critical factor." On the other hand, the study did "not support the common expectation or perception that factors outside the community's control determine whether or not a community survives." Other factors commonly thought to be important - shared ethnic heritage or the presence of newcomers, for example-also turned out to be less critical when viewed as opportunities rather than problems.

CURRENT SCHOLARSHIP on small towns continues to be fueled by these dual lines of inquiry, with one approach documenting the death and dying of individual towns on a case-by-

8. Milan Wall, "Factors in Rural Community Survival: Review of Insights from Thriving Small Towns," Great Plains Research 9 (1999), 115-35. 
case basis, adding them to the growing town cemetery founded by the first Middletown study, and the second acknowledging that not all small towns expired under modernization or the loss of local autonomy. Community of Strangers, by Joseph A. Amato and John Radzilowski, and Lancaster, Ohio, 1800-2000, by David R. Contosta, are no exception to the pattern. Community of Strangers tells the story of Marshall, a town in southwest Minnesota that also happens to be the home of Southwest State University, where Amato is Dean of the Center for Rural and Regional Studies. His coauthor, John Radzilowski, graduated from the university, published a history of Marshall through 1997, and moved away to Roseville, a community adjacent to St. Paul. Marshall is a regional center with a growing population of about 12,500. The Twin Cities are 160 miles to the northeast; Sioux Falls, South Dakota, is 90 miles in the opposite direction. Marshall's population has doubled within the last four decades, with the most "dramatic growth occurring in the late 1960s," the result of the creation of the university (6). While Marshall grows and diversifies economically (Schwan's Sales Enterprises, the home-delivery frozen food business that has become an international company employing 6,000 people, is based there), the surrounding countryside continues to empty of people. The smallest neighboring towns have, in effect, become suburbs of Marshall. At 40,000, David Contosta's hometown of Lancaster, Ohio, is more than twice the size of Marshall and also growing. Unlike Marshall's relative remoteness from urban centers, however, Lancaster sits in the shadow of a much larger city, Columbus, 30 miles to the northwest. Contosta teaches history at Chestnut Hill College in Philadelphia but grew up in Lancaster following World War II.

Marshall and Lancaster were both planned towns and have always been county seats. Theoretically, both had the potential to become a "city upon a hill," but their origins are otherwise dissimilar. Established in 1800, Lancaster celebrates its bicentennial this year. Its location was determined by Ebenezer Zane, who claimed townsites wherever the trail cleared by his family intersected major waterways. Lancaster was founded at the intersection of Zane's Trace and the Hocking River, an excellent example of the "spearheads of settlement" described by Richard 
Wade in The Urban Frontier (3). The Zanes were "town speculators who, like many others east of the Appalachians, searched out strategic points in the West where they hoped to make money by laying out a frontier town" (14). Marshall, on the other hand, was laid out three-quarters of a century later and a technological world apart from Lancaster. Platted in 1873 as a railroad town, Marshall's purpose was "no more subtle than the steam engines" that shook the town's first wooden buildings. "Marshall, like other agricultural centers, had as its purpose the connection of farm and metropolis, the West with the East" (12). It joined the "dreams" of local residents to those of distant capitalists "in the creation of a continental economic empire" (12).

Despite the apparent health and vigor of both Marshall and Lancaster, the approaches and structures of these two books are quite different, as are the authors' conclusions. Amato and Radzilowski write in a breezy, informal, and personal style. The dour tone of their title, Community of Strangers: Change, Turnover, Turbulence, and the Transformation of a Midwestern Country Town, continues inside with chapter titles such as "Decline All Around" and "The End of Main Street America." Unnumbered sections are chronologically ordered, but the main focus of the book is on the period after World War II, especially from the 1960 s and '70s to the present (it is probably no coincidence that this period matches the establishment and growth of the university in town). History is recounted in the slim volume's 88 pages of text not through names and events, but more as commentary and conclusion. There are few endnotes and no index, no illustrations of Marshall, a handful of simple statistical tables and graphs, and a wide-ranging bibliography. Community of Strangers is truly about experiential community and the damage to community wrought by change rather than the history of Marshall itself. David R. Contosta's Lancaster, Ohio, 1800-2000, on the other hand, is a more traditional local history, a case study of one town over a very long period of time. Contosta clearly dove deep into local archives for his evidence. He also read broadly in secondary literature. Chapters are arranged chronologically, and each explores essential local characteristics of the period with repeated reference to broader national contexts. Historic maps, town plats, and black-and-white photo- 
graphs of current and historic places and people augment the text. Throughout, Contosta reminds readers that the town's environment-the place itself-is tangible evidence of community history, to be read and interpreted in addition to documentary records.

Few comparisons of these two books are as telling as the authors' treatment of Main Street, the acknowledged symbol of small-town America which is undeniably affected by the automobile culture. For Amato and Radzilowski, change is evidence of the loss of local autonomy and control (assuming there ever was local autonomy), an inherently bad turn of events for small towns. Marshall's downtown, we are told, "whose business ownership is largely local in contrast to the franchise-filled strip," began its decline in the 1970s in response to new businesses that established nearer the university (40). Now, even those franchises are struggling in light of e-commerce and catalog sales. Small-town banks, too, are vanishing, with the survivors being "components of multi-county chains and big holding companies." Described as "the plight of Marshall," commerce and shopping are now spread out among a "retreating" Main Street and partially filled commercial strips (46). The authors give little attention to the effect on the consumers of goods and services, or the possibility that they enjoyed increased choice or better prices as a result of expanded commercial competition. Contosta's more nuanced review of the changes to Main Street includes the initial response of Lancaster's business and banking communities to the change automobiles brought-they tore down historic buildings for parking lots and created a "sea of asphalt." Efforts to preserve what is left have not been entirely successful, but the town has managed to combine some new corporate construction downtown with successful malls at its edge. A former mayor of Lancaster "believed that the mall kept many local residents from continuing to do a good deal of their shopping on the outskirts of Columbus and even attracted shoppers from the area directly south of Columbus itself" (259). Lancaster's mall, in other words, attracted shoppers from outside Lancaster.

The authors also interpret quite differently the influx of new residents to town-necessary for the growth of both Marshall and Lancaster. The strangers in Marshall are not just new busi- 
ness interests, but university students and faculty, former rural residents, and lately new immigrants to this country (71). Marshall, the authors conclude, "is a place of strangers by strangers for strangers. The ... newcomers that move in and out of town fill the town with turbulence and feed a growing sense of change, tumult, and irreversible transformation" (57). Couched in these terms, the sense of despair and cynicism experienced by the authors themselves seems obvious. Under Contosta's lens, on the other hand, strangers in Lancaster often brought "new vision and new energy" to town (256). Not that Lancaster escaped change or the tension of newcomers in town, but it did find ways to bring them into the fold. Parades and other regular community-wide rituals, including local high school football games, acted as "unifying spectacles" that brought residents together physically and gave them a common language (220).

Reaching very different conclusions from similar evidence of change is typical of these two books. Joseph Amato and John Radzilowski's essay clearly speaks not so much to the decline of an American small town as to the death of a small-town America. They mourn a localized "world we have lost," where Main Street merchants owned their shops and artisans practiced their trades, where residents had similar backgrounds and affiliations, and where maintaining a sense of community was easy and unchallenged. David Contosta's detailed and unblinking look at Lancaster, Ohio, leaves readers feeling they better understand small towns like Lancaster-both historically and in the present-as well as their relationship to the larger world. If attitude is important to survival in an increasingly unstable and rapidly changing world, as the Heartland Center's research may well indicate, lay your bets on Lancaster, or at least on Contosta. 
Copyright of Annals of Iowa is the property of State of Iowa, by \& through the State Historical Society of Iowa and its content may not be copied or emailed to multiple sites or posted to a listserv without the copyright holder's express written permission. However, users may print, download, or email articles for individual use. 